Article

\title{
Complement Component C3 Participates in Early Stages of Niemann-Pick C Mouse Liver Damage
}

\author{
Andrés D. Klein ${ }^{1, *(\mathbb{D}}$, Javier González de la Vega ${ }^{2}$ and Silvana Zanlungo ${ }^{2, *}$ \\ 1 Centro de Genética y Genómica, Facultad de Medicina, Clínica Alemana Universidad del Desarrollo, \\ Santiago 7590943, Chile \\ 2 Departamento de Gastroenterología, Facultad de Medicina, Pontificia Universidad Católica de Chile, \\ Santiago 8331150, Chile; jigonzalezdelavega@uc.cl \\ * Correspondence: andresklein@udd.cl (A.D.K.); szanlungo@uc.cl (S.Z.); \\ Tel.: +56-2-25785777 (A.D.K.); +56-2-23543833 (S.Z.)
}

Received: 5 February 2020; Accepted: 12 March 2020; Published: 20 March 2020

check for updates

\begin{abstract}
Niemann-Pick type C (NPC), a lysosomal storage disorder, is mainly caused by mutations in the NPC1 gene. Niemann-Pick type $\mathrm{C}$ patients and mice show intracellular cholesterol accumulation leading to hepatic failure with increased inflammatory response. The complement cascade, which belongs to the innate immunity response, recognizes danger signals from injured tissues. We aimed to determine whether there is activation of the complement system in the liver of the NPC mouse and to assess the relationship between C3 activation, a final component of the pathway, and NPC liver pathology. Niemann-Pick type C mice showed high levels of C3 staining in the liver which unexpectedly decreased with aging. Using an inducible NPC1 hepatocyte rescue mouse model, we restored NPC1 expression for a short time in young mice. We found C3 positive cells only in non-rescued cells, suggesting that C3 activation in NPC cells is reversible. Then, we studied the effect of C3 ablation on NPC liver damage at two postnatal time points, P56 and P72. Deletion of C3 reduced the presence of hepatic CD68-positive cells at postnatal day 56 and prevented the increase of transaminase levels in the blood of NPC mice. These positive effects were abrogated at P72, indicating that the complement cascade participates only during the early stages of liver damage in NPC mice, and that its inhibition may serve as a new potential therapeutic strategy for the disease.
\end{abstract}

Keywords: Niemann-Pick type C disease; complement cascade; liver damage; lysosomal storage diseases; foam cells; cholesterol

\section{Introduction}

Lysosomal storage disorders (LSDs) encompass approximately 70 different diseases that arise from deficiencies in lysosomal enzymes or transporters [1]. As a consequence of these genetic defects, partially degraded metabolites accumulate within lysosomes [2]. Niemann-Pick type C (NPC) disease belongs to the LSD group. Niemann-Pick type $C$ is caused by loss of function variants in either the NPC1 or NPC2 genes [3,4], leading to intracellular cholesterol accumulation in every tissue. The most affected organs are the brain and the liver [5]. Niemann-Pick type C 50\% of NPC patients suffer from neonatal cholestasis, jaundice, and enlarged liver and/or spleen [6]. Of these patients, $10 \%$ die from liver failure before they reach 6 months of age [7].

The complement system, which is part of the innate immune response, consists of small proteins that are capable of initiating a cytolytic response in the absence of other humoral or cellular elements. Complement activation and amplification occur on the surface of a target cell [8]. The complement cascade can be activated by the classical, the alternative or the mannose-binding lectin pathways. However, these pathways converge in the activation of a protein called C3, leading 
to the subsequent activation of C5 and cell lysis [9]. In the liver, hepatocytes are a main source of plasma complement proteins [10]. Nevertheless, other hepatic cell types (e.g., Kupffer cells, hepatic stellate cells, and sinusoidal endothelial cells) can also express different complement components [11]. The complement participates in several physiological and pathophysiological conditions. For instance, the complement receptor $\mathrm{C} 5 \mathrm{aR}$ has a role in glucose release, synthesis of proinflammatory factors, and clearance of immune complexes [12]. Also, the complement cascade participates in hepatic injury in several diseases, including non-alcoholic fatty liver disease (NAFLD) [13], alcoholic steatohepatitis [14], ischemia reperfusion [15], hemorrhagic shock [16], and others.

A recent study showed that the complement has a pathogenic role as a proinflammatory cofactor in mouse models of Gaucher disease (GD) [17]. Gaucher disease is a lysosomal disorder caused by deficiency in the lysosomal enzyme glucocerebrosidase (GCase) which causes the accumulation of glucosylceramide (GC) in the cells. This study has shown that extensive GC storage induces complement-activating IgG autoantibodies promoting C5a generation and C5aR1 activation in GD models. In turn, this response induces cellular GC accumulation, innate and adaptive immune cells recruitment and activation in GD. Indeed, pharmacological inhibition of C5aR1 prevents these inflammatory responses and increases the survival of the GD mouse. Therefore, targeting C5aR1 emerges as a potential treatment for GD patients and presumably for other LSDs.

Niemann-Pick type C patients and NPC mice models exhibit a systemic inflammatory response associated with end-organ damage and dysfunction [18]. The mechanisms that lead to tissue injury in NPC are poorly understood. Here, we studied the role of the complement cascade in NPC liver damage. We found that this pathway is highly activated during the early stages of liver disease in the NPC mouse. Interestingly, this activation seems to be reversible when the Npc1 gene is introduced in the mutant animals, mimicking a gene therapy approach. Furthermore, we found that genetic ablation of $\mathrm{C} 3$ in a $\mathrm{NpC1}^{-/-}$mouse background reduces the presence of hepatic CD68 positive cells at postnatal day 56 and prevents the increase of transaminases blood levels in NPC mice. However, these positive effects were abrogated at postnatal day 72 , indicating that the complement cascade participates only in early stages of NPC liver damage.

\section{Results}

To explore the potential activation of the complement cascade, we stained liver sections from postnatal (P) 21, 56, and 72 day old $\mathrm{Npc}^{-/-}$mice with antibodies against $\mathrm{C} 3$. To visualize the borders of the cells, we used Phalloidin-Texas Red. We found intense C 3 deposition in cuboid liver cells which is the characteristic morphology of hepatocytes in young $\mathrm{Npc}^{-/-}$mice. This strong $\mathrm{C} 3$ signal decreased with aging (Figure 1A). No positive C3 staining was found in wild-type tissues (not shown, quantification in Figure 1B). 

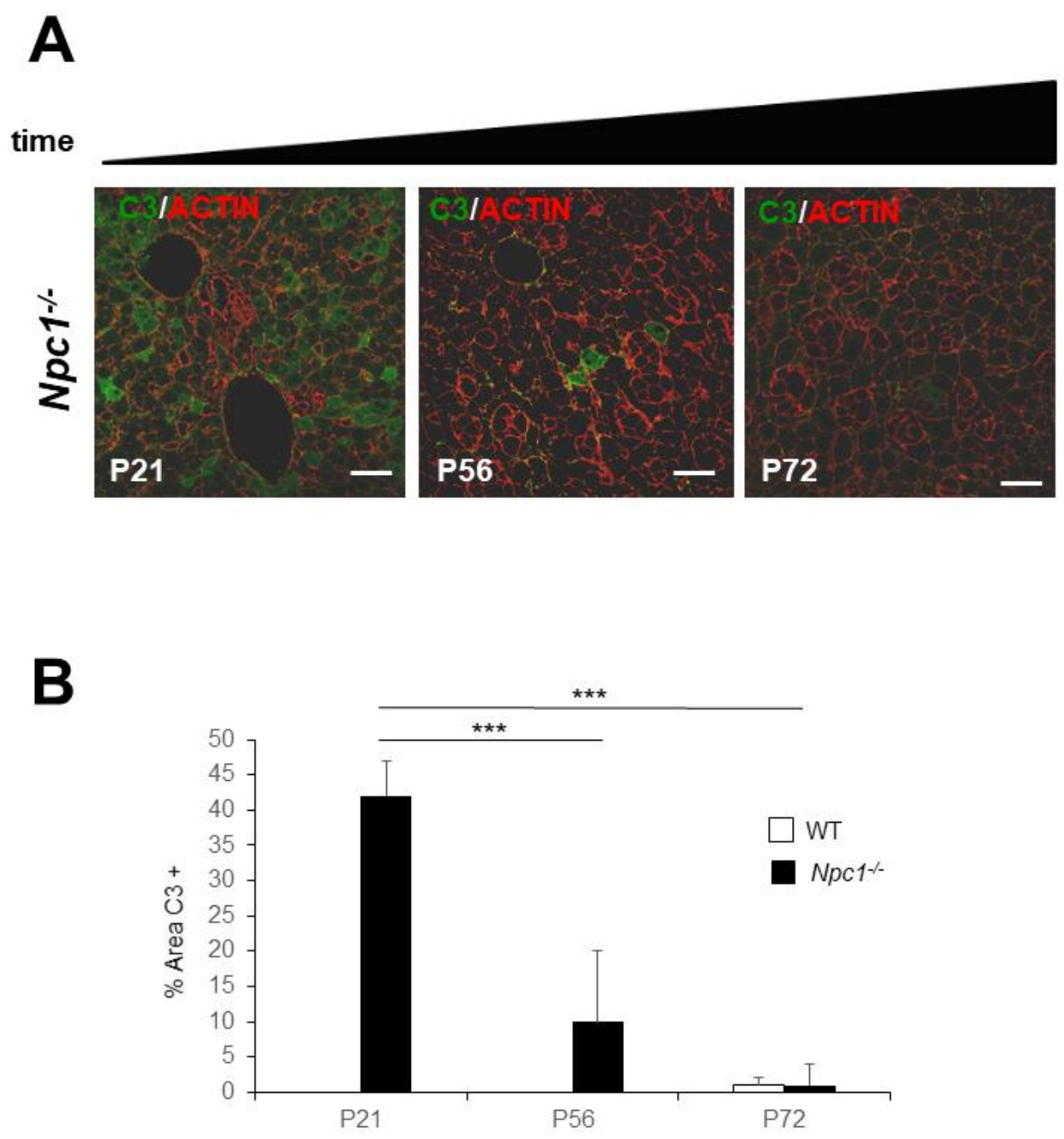

Figure 1. Complement component $\mathrm{C} 3$ (C3) deposits in Niemann-Pick type C (NPC) mouse livers decreases with aging. (A) Immunohistochemistry of $\mathrm{Npc}^{-/-}$mice livers (P21, P56, and P72 days old) showing C3 (green) and co-stained with Phalloidin-Texas red (red). (B) Quantification of the percentage of the area occupied by $\mathrm{C} 3$ positive cells at different time points in wild-type (WT) and $\mathrm{Npc1}^{-/-}$tissues. Data are presented as means \pm SD. ( $n=5$ animals/group, two-way ANOVA and Tukey's multiple comparison post-test). ${ }^{* * *} p<0.01$, compared to the $N p c 1^{-/-}$group. Scale bars are $50 \mu \mathrm{m}$.

Next, we evaluated the reversibility of complement activation by inducing NPC1 expression exclusively in hepatocytes of $\mathrm{Npc}^{-/-}$mutant mice. To this end, we used a previously developed tetracycline-inducible transgenic system to produce the NPC1-YFP protein in hepatocytes and other visceral tissues in animals that otherwise lack NPC1 [19-21]. Upon doxycycline (DOX) administration to $\mathrm{Npc1}^{-/-}$mice transgenic for ROSA26-rtTA-M2 and TRE-Npc1-YFP (abbreviated RN), NPC1-YFP was produced. However, NPC1-YFP rescue in DOX-fed R;N Npc1-/- mice was not uniform. We observed NPC1-YFP fluorescence in patches throughout the liver which fortuitously allowed us to perform mosaic analysis and compare cells that lack NPC1 with NPC1 rescued cells in the same tissue. As expected, intracellular cholesterol accumulation, visualized by filipin staining, was seen only in non-rescued liver cells (Figure 2A). Neighboring cells expressing NPC1-YFP were negative for filipin fluorescence (Figure 2A). The C3 staining revealed few $\mathrm{C} 3$ positive cells in the same tissue section (Figure 2B). Interestingly, these cells were non-rescued hepatocytes that also accumulated cholesterol as shown by the filipin positive signal (Figure $2 \mathrm{C}, \mathrm{D}$ ). These results suggest that $\mathrm{C} 3$ deposition is a reversible process that depends on the activity of NPC1. 


\section{RN; Npc1/-DOX}
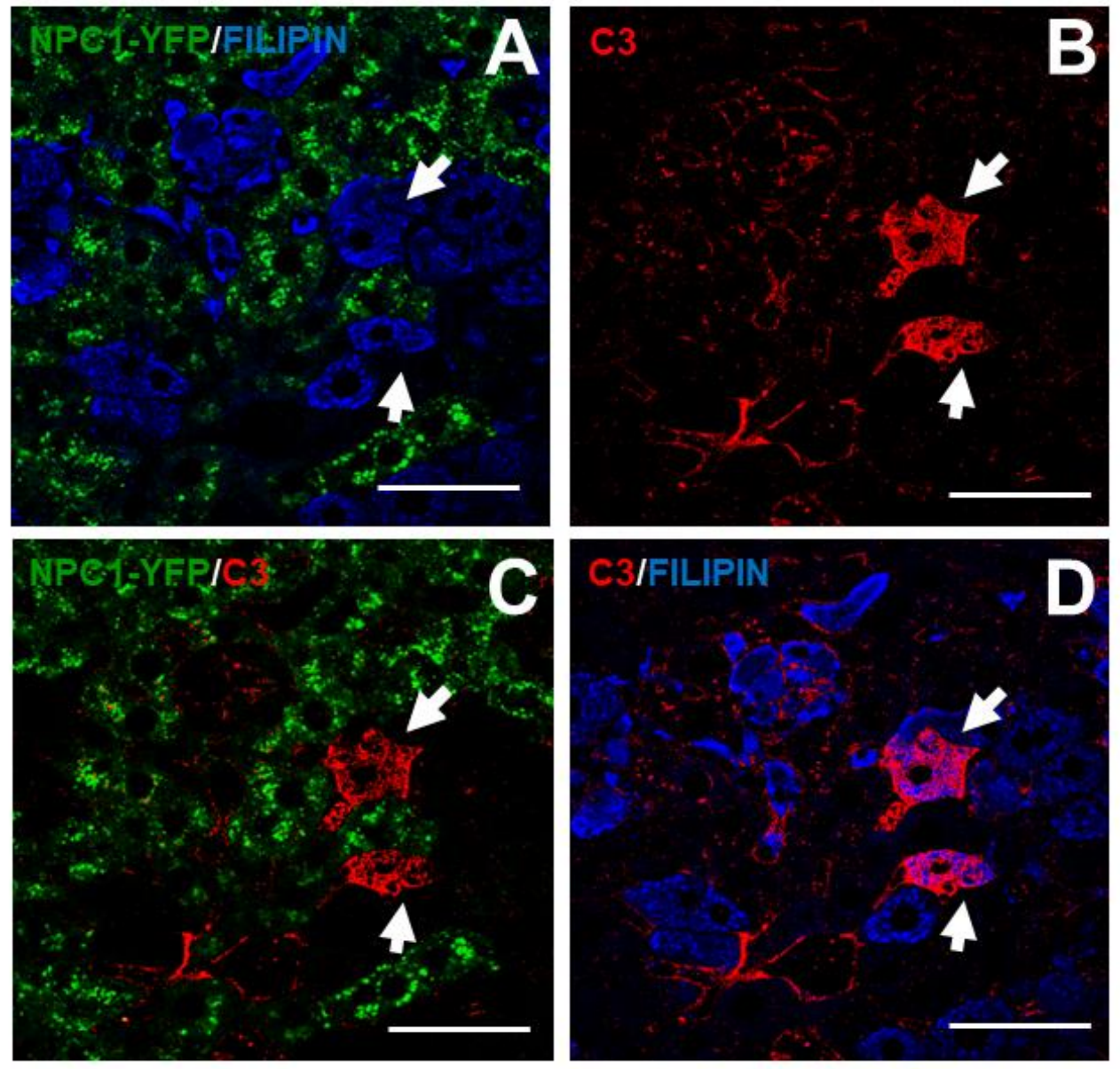

Figure 2. Reversible activation of the complement cascade in NPC livers. Expression of the Niemann-Pick type C1 protein fused with Yellow Fluorescent Protein (NPC1-YFP) transgene, driven by Rosa-rtTA in $R ; N^{-}(R ; N)$ in the $N p c 1^{-/-}$background, was induced with doxycycline from P28-33. (A) NPC1-YFP (green) and filipin staining (blue). (B) C3 staining (red). (C) Merged images showing NPC1-YFP (green) and C3 (red). (D) C3 (red) and filipin (blue) staining. Arrows indicate C3-labelled cells which were positive for filipin and negative for NPC1-YFP. Scale bars are $50 \mu \mathrm{m}$.

If the complement system contributes to NPC liver injury, then NPC mice lacking key components of this pathway should be protected from liver damage. Thus, we crossed $N p c 1^{-/-}$mice with $\mathrm{C} 3^{-/-}$ mice, and we assessed liver histology and physiological markers of liver damage at two different time points, P56 and P72. First, we stained liver sections from P56 days old mice with antibodies against CD68. The $\mathrm{C}^{-/-}$mice showed no difference in CD68 staining compared to wild-type livers (not shown). As it was previously shown, P56 Npc1-/- mice livers had a large number of round-shaped CD68 positive cells. Indeed, CD68-positive cells occupied approximately $18 \%$ of the liver area. The dko $\mathrm{Npc1}^{-/-} \mathrm{C}^{-/-}$also presented foam cells. However, the area occupied by these cells was $10 \%$ of the liver sections which is significantly lower than in $N p c 1^{-/-}$mice $(p=0.0054)$ (Figure 3A,B). As the disease progressed, we observed an increase in the area occupied by CD68 in Npc1-/- mice at P72 $(p=0.0055)$. Surprisingly, at this stage dko $\mathrm{Npc1}^{-/-} \mathrm{C} 3^{-/-}$mice showed a CD68-positive area comparable to the observed in the $\mathrm{Npc1}^{-/-}$animals $(p=0.2672)$, losing the initial protective effect. 
A

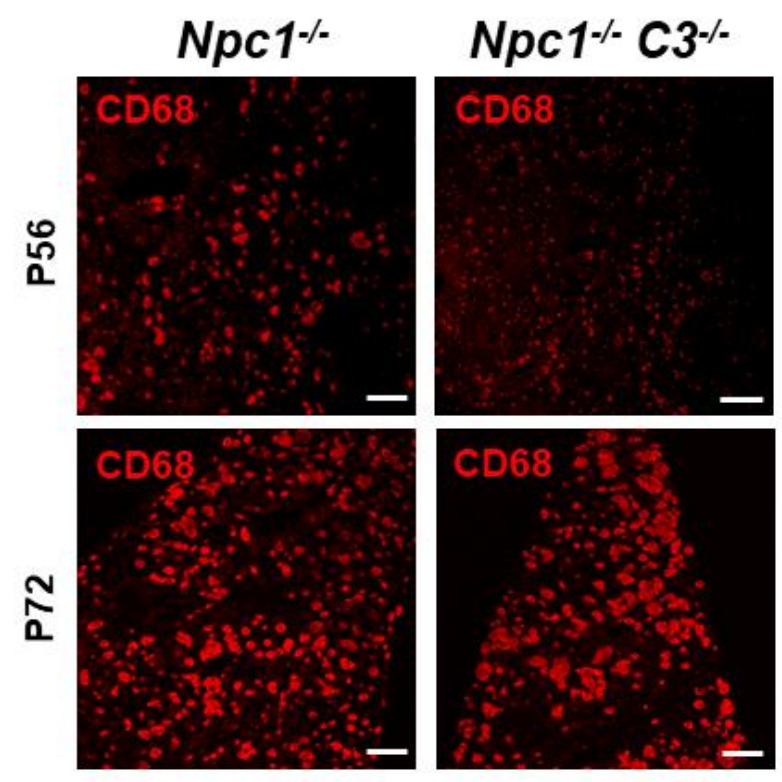

B

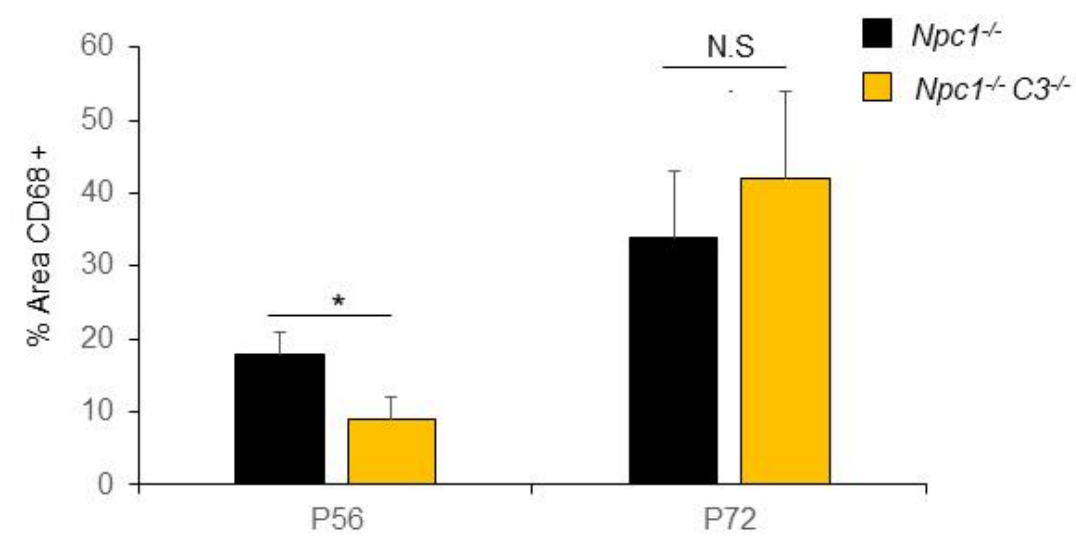

Figure 3. $\mathrm{C} 3$ ablation reduced the number of foam cells in NPC livers at P56 but not at P72. (A) CD68

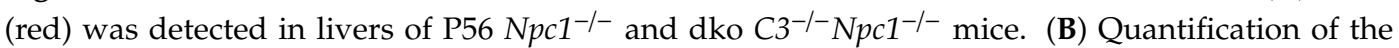
percentage of the area occupied by CD68 cells at the same time points in $\mathrm{Npc1^{-/- }}$ and $\mathrm{dko}^{-\mathrm{C}^{-/-}} \mathrm{Npc1}^{-/-}$ mice. Data are presented as means $\pm \mathrm{SD}$. ( $n=5$ animals/group, two-way ANOVA and Tukey's multiple comparison post-test). ${ }^{*} p<0.01$, compared to the $N p c 1^{-/-}$group. Scale bars are $50 \mu \mathrm{m}$.

Finally, we evaluated other liver damage markers in the same animals such as the levels of alanine and aspartate aminotransferases (ALT and AST) in the serum. The $C 3^{-/-}$mice showed no significant difference in ALT or AST blood levels compared to wild-type mice ( $p=0.1449$ and $p=0.2566$, respectively). As expected, $\mathrm{Npc}^{-1-}$ mice showed increased levels of ALT and AST compared to wild-type mice ( $p=0.0037$ and $p=0.0235$ respectively) (Figure $4 \mathrm{~A}, \mathrm{~B})$. At P56, $\mathrm{dko} \mathrm{Npc}^{-/-} \mathrm{C}^{-/-}$mice showed striking reductions in serum ALT and AST levels compared to $N p c 1^{-/-}$mice $(p=0.0161$ and $p=0.0378$, respectively) (Figure 4A,B). Congruent with previous results showing CD68 levels at P72, no differences were found in the levels of ALT and AST between $\mathrm{Npc1}^{-/-}$and $\mathrm{dko}_{\mathrm{Npc1}}{ }^{-/-} \mathrm{C}^{-/-}$mice $(p=0.9654$ and $p=0.0846$, respectively). These results demonstrate that C3 ablation prevented NPC liver damage at P56 but not at P72 and suggest that the complement cascade may serve as a new potential therapeutic target for early NPC hepatic dysfunction. 


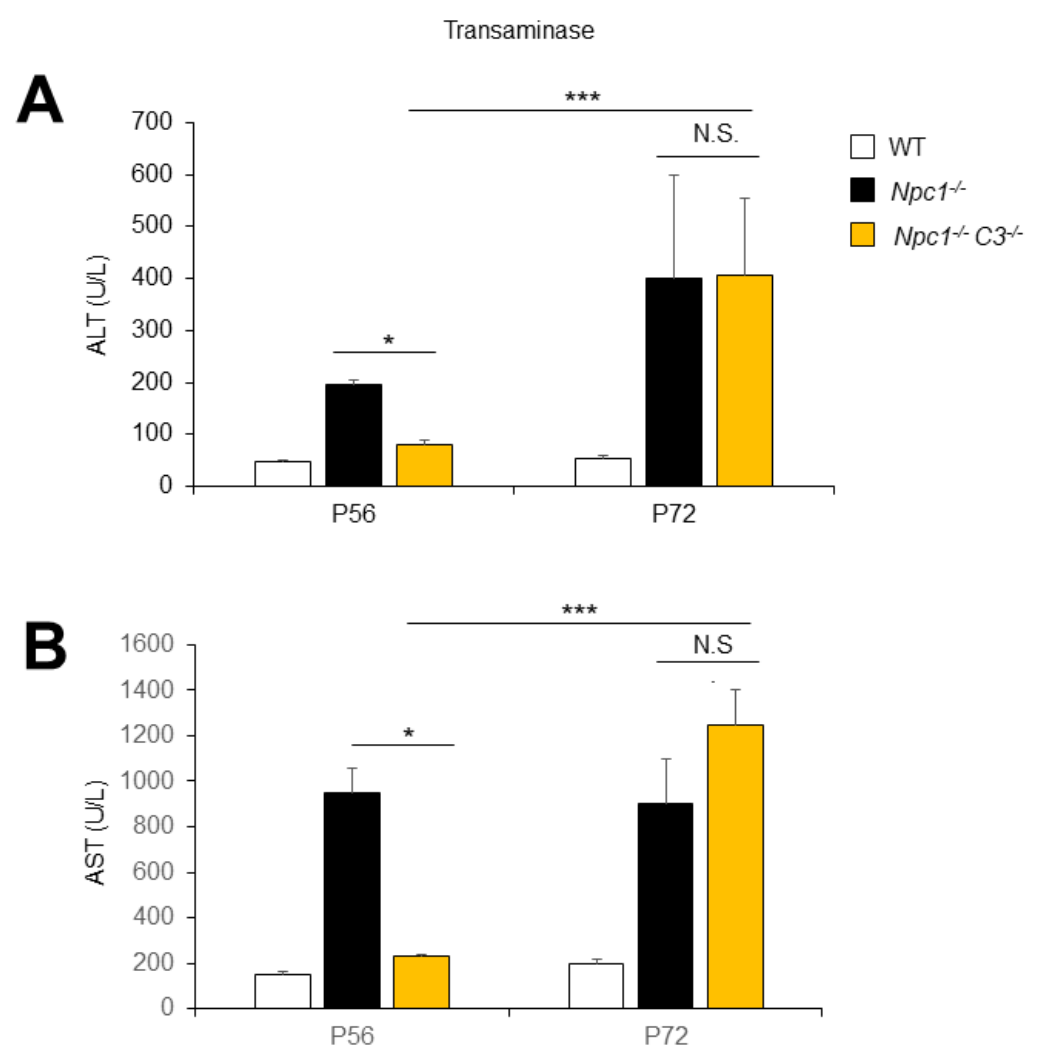

Figure 4. C3 ablation prevented NPC liver damage at P56 but not at P72. (A) Alanine and (B) aspartate aminotransferases (ALT and AST, respectively) were measured in P56 and P72 animals of the indicated genotypes. Data are presented as means \pm SD. $(n=5$ animals/group, two-way ANOVA and Tukey's multiple comparison post-test). ${ }^{*} p<0.01,{ }^{* * *} p<0.001$ compared to the $N p c 1^{-/-}$group.

\section{Discussion}

In the present study, we showed the involvement of the complement pathway during the early stages of NPC liver damage. Our results show that the activation of this pathway decreased significantly in a short period of time. Interestingly, the genetic rescue of NPC1 seemed to reverse C3 deposits in young mice. Furthermore, the genetic ablation of C3 prevented liver damage at P56 but not at P72. These results suggest that NPC liver disease behaves as an autoimmune disorder during the early stages of the disease, opening the possibility of novel therapeutic interventions in NPC patients.

The complement pathway participates in hepatic injury in several diseases such as ischemia reperfusion, hemorrhagic shock, non-alcoholic fatty liver disease (NAFLD), alcoholic steatohepatitis, and others [13-16]. Other studies have demonstrated the elevation of components of the complement cascade in the liver of patients with GD [17], the second most prevalent lysosomal disorder. In GD, GC triggers the activation of the complement which, in turn, induces further accumulation of GC thus generating a vicious cycle. Probably, this kind of circle does not occur in NPC, since cholesterol build up increases with age [22]. However, we showed that C3 deposits decrease with time, indicating disease-specific degenerative mechanisms. New investigations have shed some light on the pathophysiological role of the complement in GD. Mice deficient in the complement receptor C5aR1 are protected from developing the visceral aspects of the disease [17]. In NPC, genetic deletion of $\mathrm{C} 1 \mathrm{q}$, or of the downstream complement pathway component $\mathrm{C} 3$, did not significantly alter patterned neuronal loss [23]. Our results show that C3 ablation protects against liver damage in young mice, indicating tissue-specific pathophysiological regulation of complement in NPC.

Analogous to what has been described in other liver disorders [10,17], we observed C3 deposits in the liver of NPC mice. Unexpectedly, these deposits decreased as the mice aged. It is interesting to note that in healthy humans, plasma levels of complement components increase with aging [24]. Similarly, 
an increase in $\mathrm{C} 3$ protein levels has been observed with aging in mice tissues [25]. The mechanism of downregulation of C3 with time in NPC mice requires further investigation. It could be related to the natural turnover of hepatocytes and/or other compensatory changes in signaling pathways. The understanding of this regulatory mechanism might be relevant for other diseases with activation of the complement cascade.

Our work represents the first demonstration that inhibition of the complement cascade provides temporal hepato-protection in an NPC mouse model. However, the mechanisms that lead to its activation require further investigation. One possible modulator of the complement cascade in NPC disease is the Toll-Like Receptor 4 (TLR4) signaling pathway. The TLR4 signaling is increased in $\mathrm{Npc1}^{-/-}$mice brains and livers [26,27]. Indeed, NPC mice show hepatic increments in Tlr4 mRNA levels as early as 8 days old [27]. The TLR4 signaling leads to increments in IL-6. Interestingly, IL-6 enhances $\mathrm{C} 3$ transcription and secretion in a rat hepatoma cell line [28]. Thus, it seems probable that TLR4 signaling may contribute to the early increments in C3 deposits observed in NPC mice livers.

Previous studies have characterized NPC inflammation; however, whether liver inflammation is promoting tissue injury or protecting from it has not yet been clearly established. There are few reports describing the relevance of anti-inflammatory molecules in NPC liver dysfunction. For instance, the use of rapamycin, an FDA-approved immune suppressor, doubled the life span of NPC mice with enhanced visceral disease $[29,30]$. The hepatic engagement of other pro-inflammatory pathways has been studied as well. It was determined that TNF- $\alpha$ is increased in NPC mouse livers. The physiological relevance of TNF- $\alpha$ signaling for NPC liver damage was assessed by genetic deletion and with blocking antibodies. Both strategies led to delayed progression of NPC liver disease in mice [31,32], supporting the use of anti-inflammatory drugs to treat the hepatic symptoms of the disease.

Our experiments suggest that restoring cholesterol efflux in NPC hepatocytes, by genetically reintroducing $\mathrm{Npc1}$, can reverse C3 deposits. Another strategy to induce cholesterol efflux pharmacologically is the use 2-hydroxypropyl- $\beta$-cyclodextrin (cyclo). Cyclo injections are one of the most effective ways to treat NPC mice and cats [33-35]. Moreover, an 18 month open-label phase 1/2a trial with 14 NPC participants and monthly lumbar IT cyclo delivery showed slowing of disease progression [36]. Even one single cyclo injection at P7 induces cholesterol efflux from almost every tissue and extends NPC mouse lifespan. Cyclo injections improve NPC liver damage that is correlated with a reduction in several inflammatory markers, such as TLR4, as early as $24 \mathrm{~h}$ post injection [37]. Thus, it is feasible that cyclo treatments could be protecting from NPC liver disease by decreasing the activation of the complement cascade.

The complement cascade can directly activate hepatic macrophages [38-40]. In the past, we assessed the role of foam cells on NPC liver damage with gadolinium chloride $\left(\mathrm{GdCl}_{3}\right)$, a well-known Kupffer/foam cell inhibitor. Interestingly, $\mathrm{GdCl}_{3}$ treatment decreased the levels of $\mathrm{CD68}$-positive cells in the liver to a similar extent as the $\mathrm{C} 3$ deletion at P56. In both cases there is a normalization of transaminase levels in the serum of NPC mice [21]. This study showed that targeting foam cells with gadolinium improved NPC liver disease. Further studies are required to determine the effect of targeting foam cells on complement activation.

In summary, our results showed that the complement cascade participates during early stages of NPC liver damage, and its inhibition may serve as a new potential therapeutic strategy. Interestingly, in 2007 the US Food and Drug Administration approved anti-C5 blocking therapies for treating paroxysmal nocturnal hemoglobinuria and more recently for atypical hemolytic uremic syndrome [41,42]. Therefore, it would be interesting to study the relevance of the complement in liver disease of NPC patients, since these antibodies could be potentially beneficial for the treatment of NPC patients. 


\section{Materials and Methods}

\subsection{Mouse Strains and Genotyping}

All procedures were in compliance with national regulations set by Stanford's Administrative Panel on Laboratory Animal Care. We used $\mathrm{Npc}^{-/-}$mice in the FVB background which developed a disease indistinguishable from that in the BALB/c background [15,16]. Transgenic ROSA26-rtTA-M2; TRE-Npc1-YFP, Npc1-/- mice for liver rescue, were in the FVB genetic background. The breeding strategy to generate the strains and the genotyping protocols has been previously reported [16]. The experiments were performed at Stanford University School of Medicine. The C3 ${ }^{-/-}$mice were in the C57BL/6 genetic background and the genotyping protocol has been previously described [19]. The dko Npc1 $1^{-/-} \mathrm{C}^{-/-}$mice were in an FVB-C57BL/6 mixed background. Protocols were performed according to accepted criteria for the humane care of experimental animals and were approved by the review board for animal studies of Stanford University (APLAC protocol \#10412, 09/22/2011). Five male animals per genotype were used.

\subsection{Doxycycline Treatments}

Doxycycline (Sigma Chemicals Co., St. Louis, MO, USA) was administered in the drinking water at $2 \mathrm{mg} / \mathrm{mL}$ in 5\% sucrose, every 3 days from P28-P33.

\subsection{Immunofluorescence, Filipin Staining, and Image Quantification}

Procedures were performed as previously described [20]. Primary antibodies used were rat anti-C3 (Cederlane, Burlington, Ontario, Canada), chicken anti-GFP (Aves, Tigard, OR, USA), and rat anti-CD68 (Abd serotec, Düsseldorf, Germany). Secondary Alexa antibodies and Phalloidin Texas-Red were purchased from Invitrogen (Carlsbad, CA, USA). Filipin complex was obtained from Sigma (Sigma Chemicals Co., St. Louis, MO, USA).

\subsection{Liver Panel}

The ALT and AST analyses on mouse blood samples were performed by Stanford University Veterinary Service Center.

\subsection{Statistics}

Statistical analyses were performed using GraphPad Prism 6 (version 6, Graphpad Software Inc., San Diego, CA, USA). The ANOVA followed by Tukey's multiple comparison tests were used for statistical comparisons among the groups. Data in graphs are shown as mean \pm SEM.

Author Contributions: A.D.K. designed and performed all the experiments. A.D.K., S.Z., and J.G.d.l.V. wrote the manuscript. A.D.K. and S.Z. funded the research. All authors have read and agreed to the published version of the manuscript.

Funding: This work was funded by Fondecyt (grant \#1180337 to A.D.K. and \#1190334 to S.Z.) and by the European Union's Horizon 2020 Research and Innovation Programme (RISE) under the Marie Skłodowska-Curie grant agreement No 734825 .

Acknowledgments: We are extremely thankful to Matthew P. Scott from Stanford University for facilitating his lab resources to perform many of the experiments. We want to acknowledge Manuel Lopez for technical support and David Priestman for helpful discussions.

Conflicts of Interest: The authors declare no conflict of interest.

\section{References}

1. Platt, F.M.; d' Azzo, A.; Davidson, B.L.; Neufeld, E.F.; Tifft, C.J. Lysosomal storage diseases. Nat. Rev. Dis. Primers 2018, 4, 27. [CrossRef] 
2. Klein, A.D.; Futerman, A.H. Lysosomal storage disorders: Old diseases, present and future challenges. Pediatr. Endocrinol. Rev. 2013, 11, 59-63.

3. Carstea, E.D.; Morris, J.A.; Coleman, K.G.; Loftus, S.K.; Zhang, D.; Cummings, C.; Gu, J.; Rosenfeld, M.A.; Pavan, W.J.; Krizman, D.B.; et al. Niemann-Pick C1 disease gene: Homology to mediators of cholesterol homeostasis. Science 1997, 277, 228-231. [CrossRef]

4. Naureckiene, S.; Sleat, D.E.; Lackland, H.; Fensom, A.; Vanier, M.T.; Wattiaux, R.; Jadot, M.; Lobel, P. Identification of HE1 as the second gene of Niemann-Pick C disease. Science 2000, 290, 2298-2301. [CrossRef]

5. Klein, A.D.; Alvarez, A.; Zanlungo, S. The unique case of the Niemann-Pick type C cholesterol storage disorder. Pediatr. Endocrinol. Rev. 2014, 12, 166-175.

6. Yerushalmi, B.; Sokol, R.J.; Narkewicz, M.R.; Smith, D.; Ashmead, J.W.; Wenger, D.A. Niemann-Pick disease type $C$ in neonatal cholestasis at a North American Center. J. Pediatr. Gastroenterol. Nutr. 2002, 35, 44-50. [CrossRef]

7. Kelly, D.A.; Portmann, B.; Mowat, A.P.; Sherlock, S.; Lake, B.D. Niemann-Pick disease type C: Diagnosis and outcome in children, with particular reference to liver disease. J. Pediatr. 1993, 123, 242-247. [CrossRef]

8. Merle, N.S.; Church, S.E.; Fremeaux-Bacchi, V.; Roumenina, L.T. Complement System Part I, Molecular Mechanisms of Activation and Regulation. Front. Immunol. 2015, 6, 262. [CrossRef]

9. Ricklin, D.; Hajishengallis, G.; Yang, K.; Lambris, J.D. Complement: A key system for immune surveillance and homeostasis. Nat. Immunol. 2010, 11, 785-797. [CrossRef]

10. Gasque, P. Complement: A unique innate immune sensor for danger signals. Mol. Immunol. 2004, 41, 1089-1098. [CrossRef]

11. Schieferdecker, H.L.; Schlaf, G.; Koleva, M.; Gotze, O.; Jungermann, K. Induction of Functional Anaphylatoxin C5a Receptors on Hepatocytes by In Vivo Treatment of Rats with IL-6. J. Immunol. 2000, 164, 5453-5458. [CrossRef]

12. Qin, X.; Gao, B. The complement system in liver diseases. Cell. Mol. Immunol. 2006, 3, 333-340.

13. Rensen, S.S.; Slaats, Y.; Driessen, A.; Peutz-Kootstra, C.J.; Nijhuis, J.; Steffensen, R.; Greve, J.W.; Buurman, W.A. Activation of the complement system in human nonalcoholic fatty liver disease. Hepatology 2009, 50, 1809-1817. [CrossRef]

14. Pritchard, M.T.; McMullen, M.R.; Stavitsky, A.B.; Cohen, J.I.; Lin, F.; Medof, M.E.; Nagy, L.E. Differential contributions of C3, C5, and decay-accelerating factor to ethanol-induced fatty liver in mice. Gastroenterology 2007, 132, 1117-1126. [CrossRef]

15. Arumugam, T.V.; Shiels, I.A.; Woodruff, T.M.; Granger, D.N.; Taylor, S.M. The role of the complement system in ischemia-reperfusion injury. Shock 2004, 21, 401-409. [CrossRef]

16. Cai, C.; Gill, R.; Eum, H.A.; Cao, Z.; Loughran, P.A.; Darwiche, S.; Edmonds, R.D.; Menzel, C.L.; Billiar, T.R. Complement factor 3 deficiency attenuates hemorrhagic shock-related hepatic injury and systemic inflammatory response syndrome. Am. J. Physiol. Regul. Integr. Comp. Physiol. 2010, 299, R1175-R1182. [CrossRef]

17. Pandey, M.K.; Burrow, T.A.; Rani, R.; Martin, L.J.; Witte, D.; Setchell, K.D.; Grabowski, G.A. Complement drives glucosylceramide accumulation and tissue inflammation in Gaucher disease. Nature 2017, 543, 108-112. [CrossRef]

18. Baudry, M.; Yao, Y.; Simmons, D.; Liu, J.; Bi, X. Postnatal development of inflammation in a murine model of Niemann-Pick type $C$ disease: Immunohistochemical observations of microglia and astroglia. Exp. Neurol. 2003, 184, 887-903. [CrossRef]

19. Lopez, M.E.; Klein, A.D.; Hong, J.; Dimbil, U.J.; Scott, M.P. Neuronal and epithelial cell rescue resolves chronic systemic inflammation in the lipid storage disorder Niemann-Pick, C. Hum. Mol. Genet. 2012, 21, 2946-2960. [CrossRef]

20. Lopez, M.E.; Klein, A.D.; Dimbil, U.J.; Scott, M.P. Anatomically defined neuron-based rescue of neurodegenerative Niemann-Pick type C disorder. J. Neurosci. 2011, 31, 4367-4378. [CrossRef]

21. Klein, A.D.; Oyarzún, J.; Cortez, C.; Zanlungo, S. Gadolinium Chloride Rescues Niemann-Pick Type C Liver Damage. Int. J. Mol. Sci. 2018, 19, 3599. [CrossRef]

22. Beltroy, E.P.; Liu, B.; Dietschy, J.M.; Turley, S.D. Lysosomal unesterified cholesterol content correlates with liver cell death in murine Niemann-Pick type C disease. J. Lipid Res. 2007, 48, 869-881. [CrossRef]

23. Lopez, M.E.; Klein, A.D.; Scott, M.P. Complement is dispensable for neurodegeneration in Niemann-Pick disease type C. J. Neuroinflamm. 2012, 9, 216. [CrossRef] 
24. Gaya da Costa, M.; Poppelaars, F.; van Kooten, C.; Mollnes, T.E.; Tedesco, F.; Würzner, R.; Trouw, L.A.; Truedsson, L.; Daha, M.R.; Roos, A.; et al. Age and Sex-Associated Changes of Complement Activity and Complement Levels in a Healthy Caucasian Population. Front. Immunol. 2018, 9, 2664. [CrossRef]

25. Brink, T.C.; Regenbrecht, C.; Demetrius, L.; Lehrach, H.; Adjaye, J. Activation of the immune response is a key feature of aging in mice. Biogerontology 2019, 10, 721. [CrossRef]

26. Suzuki, M.; Sugimoto, Y.; Ohsaki, Y.; Ueno, M.; Kato, S.; Kitamura, Y.; Hosokawa, H.; Davies, J.P.; Ioannou, Y.A.; Vanier, M.T.; et al. Endosomal accumulation of Toll-like receptor 4 causes constitutive secretion of cytokines and activation of signal transducers and activators of transcription in Niemann-Pick disease type C (NPC) fibroblasts: A potential basis for glial cell activation in the NPC brain. J. Neurosci. 2007, 27, 1879-1891.

27. Liu, B.; Turley, S.D.; Burns, D.K.; Miller, A.M.; Repa, J.J.; Dietschy, J.M. Reversal of defective lysosomal transport in NPC disease ameliorates liver dysfunction and neurodegeneration in the npc1-/- mouse. Proc. Natl. Acad. Sci. USA 2009, 106, 2377-2382. [CrossRef]

28. Stapp, J.M.; Sjoelund, V.; Lassiter, H.A.; Feldhoff, R.C.; Feldhoff, P.W. Recombinant rat IL-1beta and IL-6 synergistically enhance $\mathrm{C} 3 \mathrm{mRNA}$ levels and complement component $\mathrm{C} 3$ secretion by $\mathrm{H}-35$ rat hepatoma cells. Cytokine 2005, 30, 78-85. [CrossRef]

29. Parra, J.; Klein, A.D.; Castro, J.; Morales, M.G.; Mosqueira, M.; Valencia, I.; Cortés, V.; Rigotti, A.; Zanlungo, S. Npc1 deficiency in the C57BL/6J genetic background enhances Niemann-Pick disease type C spleen pathology. Biochem. Biophys. Res. Commun. 2011, 413, 400-406. [CrossRef]

30. Calderón, J.F.; Klein, A.D. Controversies on the potential therapeutic use of rapamycin for treating a lysosomal cholesterol storage disease. Mol. Genet. Metab. Rep. 2018, 15, 135-136. [CrossRef]

31. Rimkunas, V.M.; Graham, M.J.; Crooke, R.M.; Liscum, L. TNF-\{alpha\} plays a role in hepatocyte apoptosis in Niemann-Pick type C liver disease. J. Lipid. Res. 2009, 50, 327-333. [CrossRef] [PubMed]

32. Vincent, M.; Sayre, N.L.; Graham, M.J.; Crooke, R.M.; Shealy, D.J.; Liscum, L. Evaluation of an anti-tumor necrosis factor therapeutic in a mouse model of Niemann-Pick C liver disease. PLoS ONE 2010, 5, e12941. [CrossRef] [PubMed]

33. Camargo, F.; Erickson, R.P.; Garver, W.S.; Hossain, G.S.; Carbone, P.N.; Heidenreich, R.A.; Blanchard, J. Cyclodextrins in the treatment of a mouse model of Niemann-Pick C disease. Life Sci. 2001, 70, 131-142. [CrossRef]

34. Davidson, C.D.; Ali, N.F.; Micsenyi, M.C.; Stephney, G.; Renault, S.; Dobrenis, K.; Ory, D.S.; Vanier, M.T.; Walkley, S.U. Chronic cyclodextrin treatment of murine Niemann-Pick C disease ameliorates neuronal cholesterol and glycosphingolipid storage and disease progression. PLoS ONE 2009, 4, e6951. [CrossRef] [PubMed]

35. Vite, C.H.; Bagel, J.H.; Swain, G.P.; Prociuk, M.; Sikora, T.U.; Stein, V.M.; O’Donnell, P.; Ruane, T.; Ward, S.; Crooks, A.; et al. Intracisternal cyclodextrin prevents cerebellar dysfunction and Purkinje cell death in feline Niemann-Pick type C1 disease. Sci. Transl. Med. 2015, 7, 276ra26. [CrossRef] [PubMed]

36. Ory, D.S.; Ottinger, E.A.; Farhat, N.Y.; King, K.A.; Jiang, X.; Weissfeld, L.; Berry-Kravis, E.; Davidson, C.D.; Bianconi, S.; Keener, L.A.; et al. Intrathecal 2-hydroxypropyl- $\beta$-cyclodextrin decreases neurological disease progression in Niemann-Pick Disease, type C1: An ad-hoc analysis of a non-randomized, open-label, phase 1/2 trial. Lancet 2017, 390, 1758-1768. [CrossRef]

37. Yanjanin, N.M.; Velez, J.I.; Gropman, A.; King, K.; Bianconi, S.E.; Conley, S.K.; Brewer, C.C.; Solomon, B.; Pavan, W.J.; Arcos-Burgos, M.; et al. Linear clinical progression, independent of age of onset, in Niemann-Pick disease, type C. Am. J. Med. Genet. B Neuropsychiatr. Genet. 2010, 153, 132-140. [CrossRef]

38. Schieferdecker, H.L.; Schlaf, G.; Jungermann, K.; Götze, O. Functions of anaphylatoxin C5a in rat liver: Direct and indirect actions on nonparenchymal and parenchymal cells. Int. Immunopharmacol. 2001, 1, 469-481. [CrossRef]

39. Mack, M.; Cihak, J.; Simonis, C.; Luckow, B.; Proudfoot, A.E.I.; Plachy, J.; Schlondorff, D. Expression and Characterization of the Chemokine Receptors CCR2 and CCR5 in Mice. J. Immunol. 2001, 166, 4697-4704. [CrossRef] [PubMed]

40. Schlaf, G.; Nitzki, F.; Heine, I.; Hardeland, R.; Schieferdecker, H.L.; Götze, O. C5a anaphylatoxin as a product of complement activation up-regulates the complement inhibitory factor $\mathrm{H}$ in rat Kupffer cells. Eur. J. Immunol. 2004, 34, 3257-3266. [CrossRef] 
41. Hillmen, P.; Young, N.S.; Schubert, J.; Brodsky, R.A.; Socié, G.; Muus, P.; Röth, A.; Szer, J.; Elebute, M.O.; Nakamura, R.; et al. The Complement Inhibitor Eculizumab in Paroxysmal Nocturnal Hemoglobinuria. N. Engl. J. Med. 2006, 355, 1233-1243. [CrossRef] [PubMed]

42. Wehling, C.; Amon, O.; Bommer, M.; Hoppe, B.; Kentouche, K.; Schalk, G.; Kirschfink, M. Monitoring of complement activation biomarkers and eculizumab in complement-mediated renal disorders. Clin. Exp. Immunol. 2016, 187, 304-315. [CrossRef] [PubMed]

(C) 2020 by the authors. Licensee MDPI, Basel, Switzerland. This article is an open access article distributed under the terms and conditions of the Creative Commons Attribution (CC BY) license (http://creativecommons.org/licenses/by/4.0/). 